Please do not remove this page

RMIT

UNIVERSITY

\title{
The uberisation of housing markets: Putting theory into practice
}

Sharam, Andrea; Bryant, Lyndall

https://researchrepository.rmit.edu.au/esploro/outputs/9921861690401341/filesAndLinks?institution=61RMIT_INST\&index=null

Sharam, A., \& Bryant, L. (2017). The uberisation of housing markets: Putting theory into practice. Property Management, 35(2), 202-216. https://doi.org/10.1108/PM-06-2016-0023

Document Version: Accepted Manuscript

Published Version: https://doi.org/10.1108/PM-06-2016-0023

Repository homepage: https://researchrepository.rmit.edu.au

(c) Emerald Group Publishing

Downloaded On 2023/04/26 19:40:38 +1000

Please do not remove this page 
Thank you for downloading this document from the RMIT Research Repository.

The RMIT Research Repository is an open access database showcasing the research outputs of RMIT University researchers.

RMIT Research Repository: http://researchbank.rmit.edu.au/

\section{Citation:}

Sharam, A and Bryant, L 2017, 'The uberisation of housing markets: Putting theory into practice', Property Management, vol. 35, no. 2, pp. 202-216.

See this record in the RMIT Research Repository at:

https://researchbank.rmit.edu.au/view/rmit:42760

Version: Accepted Manuscript

Copyright Statement:

(C) Creative Commons Attribution Non-commercial International Licence 4.0 (CC BY-NC 4.0).

\section{Link to Published Version:}

https://dx.doi.org/10.1108/PM-06-2016-0023 


\title{
Uberisation of housing markets: Putting theory into practice.
}

\author{
Authors: \\ Dr Andrea Sharam \\ Swinburne Institute for Social Research \\ 0392145465 \\ asharam@swin.edu.au \\ Dr Lyndall Bryant \\ Queensland University of Technology \\ 0731384415 \\ lyndall.bryant@qut.edu.au
}

\begin{abstract}
Purpose

Digital disruption offers an innovative opportunity to address housing affordability issues through the use of market design theory and two sided matching markets. This paper scopesa model for how 'uberisation' can revolutionise the traditional apartment delivery model in Australia, leading to improved housing affordability.
\end{abstract}

Design/methodology/approach

We use semi-structured interviews with operators of online real estate platforms and deliberative developers to examine how the principles of 'uberisation', that is two sided matching markets, are driving innovation in the apartment supply process.

Findings

Findings confirm that real estate internet platforms and deliberative developers innovators are informed by the benefits of aggregating demand to reduce development risk, thus enabling apartments to be provided at a substantially lower price than by traditional methods.

Research limitations/implications

The number of interviews is small reflecting the limited number of market actors currently engaged in the innovations investigated.

Originality/value

This research is innovative as it introduces theoretical understandings gained from market design theory and applies those concepts to disrupt the apartment development process.

\section{Key words}

Digital disruption, market design, housing affordability, apartments, uberisation, deliberative development, two-side matching markets, Australia, internet, residential property development 


\section{Introduction}

The purpose of this article is to scope how digital disruption or 'uberisation' and the market design theory underpinning e-commerce technology platforms such as Uber and AirBnB, can be utilised to transform traditional apartment development in Australia and potentially elsewhere, and thus lead to improved housing affordability and sustainability outcomes.

The Australian apartment development is inefficient, characterised by its inability to effectively match owner-occupier demand with suitable supply in an orderly and sustainable manner (Authors 2015a). At the same time declining housing affordability is a major social and economic issue in Australia (Burke, 2012; NHSC, 2013; Rowley and Phibbs, 2012), a problem that has not been resolved by the regular reset of urban growth boundaries, the provision of new greenfield land and a surge of high rise residential tower construction in capital city centres.

This market failure results in: under-supply, over-supply, supply limited to certain locations, and product that is unnecessarily expensive and undesirable to owner occupiers, especially families. Further, with the exception of the luxury end of the market, supply is insensitive to the demands of would be owner-occupiers with most apartment product being generic, poorly designed, of poor quality and located primarily in inner city locations (Government of Victoria, 2015). Fundamentally, these problems are due to market failure associated with high search costs and a lack of 'trust' between buyers and sellers that cannot be remedied through use of legal contracts (Authors 2015a).

Market design theory provides an innovative approach to understanding the supply of housing, and offers a practical solution to promote affordable apartment supply (Authors, 2015a and b). In contrast to classical economics focus on equilibrium resulting from the behavior of rational actors and competition, market design, does not take market efficiency as given. Instead, it takes lessons from game theory (which focuses on strategic behavior of actors and cooperation in markets) and results from empirical work and experimental analysis to aid in the design and implementation of actual markets (Vulkan et al., 2013).

This research hypothesises that 'uberisation' or the application of market design, and more specifically internet-enabled two-sided matching markets, is an emerging disruption to the apartment development market that can overcome longstanding market failures in the supply of apartment product and the productive densification of our cities. Understanding of market design outside of the economics, information technology and to a lesser extent management disciplines appears to be rare, despite its widespread contribution to the growth of ecommerce. This research is innovative as it introduces theoretical understandings gained from other digitally disrupted markets and market design theory and applies them to housing supply.

The article proceeds as follows. The following section introduces market design and more specifically two-sided matching markets. Section three describes market failures associated with the apartment development model that exists in Australia and outlines how market design theory can be adapted to provide more affordable apartment options for owner-occupiers. Section four outlines the methodology of this research project, seeking evidence on the emergence of such 'uberisation' in the Australian apartment market. Section five provides the findings and section six concludes. This research provides an early insight into the evolving trend of digital disruption in housing markets. 


\section{What is market design?}

Mainstream economics traditionally focuses on competition as the force that increases productivity. Market design is a branch of game theory, a field of economics that examines the strategic decision-making of intelligent, rational actors and hence focuses on cooperation rather than competition (Myerson, 1991). According to game theorists, markets have 'rules of the game': if the rules provide the right incentives, economic actors, behaving rationally will follow these rules in order to maximise profits. As rational actors they will subvert the rules where the incentive to do so exists and will cooperate if there is an advantage in doing so (Myerson, 1991). Game theory has become a key way of understanding monopolisation and collusion, with market design emerging as a means of fixing markets to promote competition, or creating 'markets where there were none' (Roth 2007, p. 1). Market design recognises that markets exist within existing social structures for example, political and legal systems. This differs from the neo-classical understanding of markets, which posits markets as 'simply the confluence of supply and demand' (Roth, 2007, p. 1). Taking the understanding of markets as embedded in wider systems, market design posits markets as 'constructions' that have been designed and which have rules that evolve over time in response to the economic environment (Roth, 2002). This presupposes that there is no single market design or construction. This too is a departure from neo-classical economics, which suggests a (simple) universal design.

For the purposes of disrupting housing markets, our focus is on a specific form of market, 'twosided matching markets':

One of the main functions of many markets and social processes is to match one kind of agent with another: e.g. students and colleges, workers and firms, marriageable men and women...A market is two-sided if there are two sets of agents, and if an agent from one side of the market can be matched only with an agent from the other side. (Erev et al., 2002, pp.360)

Roth (2015) outlines the pervasiveness of matching markets, and why many do not currently function well, and how Uber and Airbnb use the precepts of market design to improve market outcomes. The buying and selling of houses is one matching market he criticises.

Ideally in a matching market no agents should be left on opposite sides of the market that were not matched to each other and would both prefer to be. Marriage is the most often cited example of a two-sided matching market. Just as matchmakers are used to connect potential marriage partners, two-sided matching markets rely on a 'market manager' or clearinghouse to coordinate agents (Roth, 1984).

The market manager is responsible for recruiting and aggregating the agents who are required to hold formal membership of the market; and performs the key role of coordinating transactions. This explicit membership and aggregation into a demand-side pool and a supplyside pool resolves the critical issue of the search by narrowing the field and matching the preferences of the two parties.

The seminal theoretical foundations for market design were laid down by Gale and Shapely's (1962) work on algorithms to process preferences. The insights of that work were progressed by Roth who created a two-sided matching market for intern placements in the US (in the early 1990s) and for live-human kidney donation (in the mid-2000s). These applications of market design are highly celebrated (Roth was awarded the Nobel Prize for Economics for this work) and have generated a huge literature, albeit primarily within the economics discipline. The learning was rapidly applied to E-commerce (Kittsteiner and Ockenfels, 2006), to native 
vegetation offsets (Stoneham et al., 2003; Crowe, 2008); and has been proposed for markets as diverse as vocational education and training (Cooney, 2008); and accounting of environment services (Stoneham et. al., 2012). In relation to real property the application to housing has been very limited although profitable. Simultaneous auction of multiunit dwellings, has been found to raise the prices achieved by vendors (Goeree et al, 2004; Kwasnica and Sherstyuk 2013). Otherwise investigations have remained theoretical rather than practical (e.g. Wheaton, 1990; Genesove and Han, 2012; Albrecht et al., 2007).

Vulkan et al., (2013) argue a properly functioning two-sided matching market must have four prerequisites: 'Thickness', 'Safety', 'Simplicity' and a lack of 'Congestion'. The first, Thickness, refers to the need for a sufficient number of buyers and sellers to deliver satisfactory outcomes for both sides of the transaction. This means 'many potential transactions need to be available at the same time, so that relevant offers can be compared' (Vulkan et al., 2013: p. 3). The second condition is that the participants must be Safe. Successful transactions are highly reliant on both buyers and sellers having the confidence and incentive to reveal or act on the information they hold. Participants need to believe they can make their transactions with confidence in the outcome. This in part reflects the need for Simplicity: of rules and their transparency, but also avoiding the need for complex strategising. Finally, the market needs to avoid Congestion. Transactions need to be conducted efficiently and quickly, 'giving participants enough time - or the means to conduct transactions fast enough - to make satisfactory choices when faced with a variety of alternatives' (Roth, 2007, p. 2).

The internet, computational power and new algorithms have been critical in achieving the requisite efficiencies to avoid congestion in new markets such as Uber, the peer-to-peer car ride service that matches passengers with drivers, or the private accommodation service Airbnb. But neither of these services or others, would be successful without large, active memberships that ensure services are available whenever demanded (thickness). This thickness attests to not only demand being satisfied but to consumer interfaces that make it extremely easy to use the services (simplicity). The prevalence and uptake of mobile phone applications for these markets demonstrates the importance of simplicity. Being safe has multiple meanings. Across the board E-Commerce has had to ensure the process of monetary exchange is secure and customers' personal information is protected. Buyers however also need to have confidence that the product they receive is what they thought they were purchasing. Some markets however also need to consider personal safety. These types of issues have given rise to strategies that permit market participants to actively engage in rating services, with reputation as a key safety mechanism.

Market design also brings renewed attention to critical issues facing markets, which Milgrom (2011, p. 311-319) outlines as:

- Product definition - what is the commodity and how should it be defined?

- Messages - how do participants communicate in markets?

- Incentives - the trade-off between the level of information disclosure and truthful reporting and

- Linkages among markets - how trade in different goods are linked.

These critical issues draw our attention to how the apartment development market is 'broken', and why it needs to be fixed. Product definition is important in the context of supply of affordable apartments. Currently, apartments in Australia are produced as commodities rather 
than as homes for owner-occupiers (Birrell and Healy, 2013). As investors purchase around $80 \%$ of new stock offered for presale it is they rather than intending owner-occupiers who are the target of Messages. Marketing of presales is largely a one-way process dominated by traditional advertising strategies and few buyers have the opportunity to articulate and communicate their preferences.

The information disclosure and truthfulness associated with various Incentives is a multifaceted problem. Tactical withholding of information by developers and their sales agents exacerbates problems currently associated with pre-sales and renders the pre-sale process unSafe. The buyer, as a rational agent, in certain circumstances has strong incentives to avoid settlement (such as when apartment values have declined), and the developer is incentivised in some circumstances to abandon projects (such as when site values have increased). If both buyer and developer were more certain settlement would take place as agreed, the transaction would be assured and much of the development risk would be removed. Greater disclosure and more attention to consumer preferences by developers would enable better alignment of interests, increased consumer satisfaction, greater trust between the two parties and thus increase the Safeness of the transaction and increase the likelihood of settlement proceeding as intended by the pre-sale contract.

Finally, how trade in different goods has many facets in relation to apartment development, with credit provision and land supply obviously connected markets. However, it also draws our attention to how housing and land are commoditised, and how land speculation is highly detrimental to housing affordability with many developers preferring to on-sell an apartment site and take a "risk free" return when site values increase. This again indicates a lack of incentive alignment between buyers of apartments and suppliers.

With the emergence of the internet, key search and transaction costs can be addressed enabling many markets to be restructured to operate more efficiency, a process widely described as 'disruption'. Market design provides a solid theoretical and practical understanding of the economics of such digital disruption.

Market design permits the creation of markets where none existed, or can fix markets where they do not function efficiently. Our proposition that market design is a solution to providing more affordable apartments therefore requires an understanding of how the existing market fails. The next section examines how the traditional market for apartments operates, highlighting the current market failures that contribute to reduced housing affordability.

\section{Market failure in the traditional market for apartments}

The traditional apartment market structure fails to efficiently match developer supply with consumer (owner-occupier) demand. High search costs for finding buyers pushes up the cost of supply, narrowing the potential margin available in a process in which prices (hence revenue) are locked in sometimes years before project completion while many costs remain subject to change. Price volatility, reflecting the boom and bust cycle that is a feature of Australian property market, also means developers face the risk that pre-sales will not settle. The problem for would-be owner-occupiers is that typical apartment product is not price competitive with detached housing, is of poor quality and design, with little variation in product. Despite urban consolidation policies being widely adopted by Australian governments since the 1980s as a means of containing urban sprawl, and as a means to overcome the national shortage of housing (NHSC, 2013) owner-occupied apartments (as opposed to rental stock) 
have made only a modest contribution to new housing supply.

In an efficient market, demand is forecast and a steady supply of the desired product is produced to match that demand. Production can be readily adjusted in accordance with changes to demand patterns. In apartment development, this efficiency is virtually impossible to achieve primarily due to the length of time from project inception to completion and project debt financing structures.

Currently, developers rely on a number of proxies to forecast the strength of future housing demand. Lead indicators include: population growth, employment participation, wage growth, migration, housing supply, patterns of household formation and historical sales etc. In order to ensure this forecast demand is converted into sales revenue, the product is pitched to the lowest common denominator, which in Australia is an investor seeking rental yields in the short term and capital gain in the longer term (supported by generous taxation arrangements not available to owner-occupiers). The apartment product for this market is highly generic, in a city centre high rise location, tends to be poorly designed with poor amenity with too little attention given to the lifecycle costs or the cost of living in an apartment (Government of Victoria, 2015). The other main supply of apartments is at the luxury end of the market. Upmarket owner-occupiers seek water or parkland views, high neighbourhood amenity and so-called 'lifestyle' locations such as major entertainment precincts. The result leaves low to middle income aspiring owner-occupiers with no supply to satisfy their demand for affordable apartments in suburban locations. This is a market failure.

Pre-sales (or 'off the plan' sales) are a risk mitigation tool used by development financiers. They are a mechanism used in the traditional apartment development model to lock in demand (future revenue) prior to construction of the building. The ultimate purpose of the pre-sale contract is to 'guarantee' settlement at the physical completion of the project, and hence guarantee the repayment of the project finance loan (Bryant, 2012). Thus developers and their financiers are highly exposed if pre-sales fail to settle upon completion of construction. The problem is market conditions may fluctuate in the time (often years) between pre-sale contacting and project completion. Property values may fall, interest rates and input costs may rise, increased competition may result in over-supply, credit conditions may tighten. Buyers are prone to forfeit their pre-sale deposit (which in Australia is a maximum of $10 \%$ of the sale price) if the value of the property declines over this period, and mortgage financiers can withdraw offers of finance making settlement difficult or impossible even if the buyer wishes to proceed with the contract. Obtaining legal remedy if buyers opt out of the pre-sale contract can be difficult for developers in practice because of the cost of litigation and reputational hazards. A pre-sale contract therefore only effectively reduces the developer's settlement risk in a rising market (but those conditions increase the buyer's settlement risk).

Pre-sale campaigns are often both time-consuming and expensive because the developer, in pursuing buyers, is looking for proverbial 'needles in a haystack'. A pre-sale campaign typically comprises 10 per cent of project costs and represents, in economic terms a significant search and transaction cost (Authors, 2015b).

Another problematic aspect of apartment development in Australia is the oligopolistic structure of the industry (Coiacetto, 2009). The market has little Thickness with few suppliers and if cost savings are achieved, a lack of competition means these cost savings may not be automatically passed through to buyers.

High search costs, and high risk associated with property settlement reflect difficulties in 
managing demand for apartments. With higher risks come higher return expectations and the combination of high marketing costs and increased return benchmarks adversely affect assessment of project viability. Project proposals forecast minimum rates of return (20 per cent). If this is not achievable projects do not proceed. Unlike commodity markets, prices are not forced downwards.

The use of two-sided matching markets theory to inform disruption of property development is new in the Australian and international context, but is not entirely without a precursor.

\section{Baugruppen}

Consumer dissatisfaction with apartment product supplied by traditional market processes has resulted in 'deliberative development' whereby apartment development is undertaken by a group of intending owner-occupiers who take the place of the speculative developer (Authors 2015 a, b). In Germany Baugruppen (translation 'building groups), and 'group-build' syndicates in the UK reflect do-it-yourself deliberative development models that aggregate like-minded intending owner-occupiers who design and build their own apartment buildings in accordance with the preferences of the members. Such deliberative development processes address settlement risk by increasing the 'stickiness' or attachment of the buyer by permitting them to obtain the product that want. Deliberative developments have demonstrated consistent and significant cost savings and unlike speculative-based developments, tailor projects to suit the diversity of households involved and embody other collective ambitions, such as higher environmental performance (Dolin et al., 1992; Lloyd et al., 2015; Ring, 2012). Deliberative development is itself a disruptive development model being used to realise owner-occupier apartment preferences in Australia and is nexus for this research.

Deliberative development models such as baugruppen reflect the basic tenets of a two-side matching market. Buyers are aggregated prior to projects, often by a third party (a protomarket manager). Buyer groups are then linked to housing producers (in Germany, architectled teams who project manage). Better alignment of interests enables 'trust' and 'safeness', which have positive consequences for product and cost.

To this point, we have presented a hypothesis that there is an existing problem with the apartment development market that market design could address and thus de-risk development and contribute to improved affordability and enhanced consumer satisfaction. In the next section, we interview new market actors in the apartment development industry whose business models reflect various tenets two-sided matching markets to test our hypothesis. 


\section{Methodology}

This paper considers how the economic theory underpinning e-commerce technology platforms, market design (and specifically a two-sided matching markets), may be utilised to de-risk apartment development, and thus contribute to improved housing affordability and apartment product. To answer this question semi-structured interviews with operators of online real estate platforms and 'deliberative developers' were used to examine how the principles of market design are driving innovation in the apartment development process. Interviews were held with principals of three internet platforms that match buyers of apartments with development opportunities or aggregate demand for deliberative development, and principals of two deliberative developers.

The internet platforms of interest in this research need to be distinguished from real estate crowdfunding platforms. There are a growing number of real estate crowdfunding platforms in Australia as there are internationally. These platforms match equity (and sometimes debt) investors to development opportunities rather than housing consumers with development opportunities that specifically respond to their articulated preferences. We did interview the founder of one of these new equity crowdfunding platforms. This informant was well aware of two-sided matching markets and regarded his business as an example. The interview was excluded on the basis that the disruption concerned the banking model rather than the development model.

One of the subjects withdrew consent after the interview so the data from that interview is not used. Publicly available data on that platform has been used instead. The others agreed to be identified. Four of the five informants were Melbourne based. Each of these was interviewed in person. The fifth is an existing German business intending to establish in Melbourne. This informant was interviewed via Skype. The interviews took place in October 2015. The semistructured interviews included questions about their qualifications, skills and experience; explanation of their business model; why they had established the business and what they wanted to do with it in the future; and how they understood the theoretical underpinnings of the models they were using.

The emergence of these businesses in Melbourne can in part be explained by the combination of strong population growth in Melbourne (with Melbourne expected to overtake Sydney as Australia's largest city between 2030 and 2050) and the relative affordability of residential property in Melbourne when compared to Sydney. In addition there has been a surge of interest in the baugruppen movement more generally.

Searches of specialist real estate media such as The Fifth Estate and property industry websites such as Urban Melbourne and Urban Taskforce suggest these businesses are unique in Australia. Searches for international examples revealed nothing that was similar to the Melbourne initiatives. The exception is the Local Self-Build Register in the UK that has been established as part of the Right to Build legislation, which will be a register of people interested in self and custom build. Local governments in the UK will be required to offer plots of land to groups who request them. This initiative follows the German experience in which many local governments effectively zoned parts of greenfield and brownfield development sites for baugruppen projects. As such we felt the Register, while of interest, was out of scope for this research. While this meant our sample is small it nevertheless captures the pioneers on the edge of disruption. 


\section{The interviewees}

The first internet platform is Citiniche an online property development platform founded by Ivan Rijavec, a Melbourne architect. Launched in 2012 it explicitly sought to aggregate and then segment buyers into communities (niches) that could be matched to developers who could then respond to these collective aspirations. Rijavec proposed 'Crowdfunding', as means to obtain financing for projects (Edgar, 2015), presumably to allow groups to avoid both mainstream financiers and developers thus provide buyers with more control over the apartment product. Crowdfunding on the scale required however is not yet feasible in Australia. To date Citiniche has attracted little buyer interest if the number of niche members indicated by the website is an indication. The publicly available material suggests Citiniche has been associated with only two developments. As these project developers also adopted conventional presale campaigns it is likely that even if buyers joined the projects via Citiniche, it is unlikely they drove outcomes on the sites.

The second Internet platform is Apartment Register, a start-up whose founder Cameron Clarke, has background in hotels and real estate, and holds finance and economic qualifications. Apartment Register matches clients looking for off the plan sales to development opportunities. The focus is on quality product and responsiveness to buyers. Clarke says inquiries are high and very clear market segments have emerged.

Group Estate is a German platform working within the German baugruppen sector. Founder Joel Dullroy, is an Australian ex-patriot who intends to expand his business internationally with Australia and Melbourne in particular likely to be the first addition. Group Estate was initially established to assist group purchase/ownership of existing dwellings but Dullroy recognised that group-build was more practical, and that the baugruppen sector lacked a sophisticated communications platform.

Property Collectives is a firm, which manages residential property syndicates and their development projects. Property Collectives specialises in townhouses for relatively wealthy investors and includes owner-occupiers and investors/landlords (with some of the syndicate members being both owner-occupiers and investor/landlords) who seek high quality design and environmentally sustainable development. These members are able to bring considerable equity to projects and have experienced no difficulty in obtaining development finance. Founder Tim Riley has a background in commerce and marketing.

Nightingale Housing is a not-for-profit company created by a consortium of architectural firms, led by Breathe Architecture principal Jeremy McLeod to provide market-based apartments within the existing urban footprint. Nightingale Housing focuses on design and environmentally sustainable development and returns the developer margin to buyers, either in price reductions or further environmental initiatives. A future aim of the Nightingale Housing is to create a cooperative group-build model that can deliver greater affordability as well as improve the quality of the built form. 


\section{Findings}

Having introduced the informants, the discussion now turns to how they understand the market's failings and how their innovation is either implicitly or explicitly informed by knowledge of digital disruption, market design and two-sided matching markets. Specifically, we wanted to know if our informants perceived the market as broken or if they felt they were creating a market where one did not previously exist. Did they have formal knowledge of twosided matching markets, and had they considered Vulkan et al.'s (2013) prerequisites of simplicity, congestion, thickness and safety. And finally, following Milgrom (2011), did they identify issues concerning product definition, messages, truthful reporting, and the linkages among markets.

\section{A broken market}

Each of the informants saw declining housing affordability as a concern, and apartments as the main source of new dwellings in the inner to middle suburbs. McLeod, Rjavec and Clarke were keenly aware that outside of the luxury end of the market, would-be owner-occupiers of apartments had little choice in a market that supplies highly generic product that is commonly poorly designed and built.

It's a reaction against the crap that's out there and against every... apartment that doesn't serve the person who lives it...people are sick of going through apartments and beige on beige (Rijavec, Cited in Edgar, 2013)

Clarke indicated his frustration that his developer clients did not respond more deliberately to the demand from his buyer clients.

The local market was frustrated...the product that they want [is] not actually being supplied. So we... say to developers "Look, we have a hundred people in Fitzroy that want this product. If someone could please just ask us before you design it to what you think the market want, to us, we'll be able to just mix and match a bespoke design building that matches everyone in terms of affordability, design and everyone's happy"...And even a step ahead of that is actually asking the market what they actually want (Clarke)

The informants clearly regarded the market as problematic if not broken. McLeod, Clarke and Riley each identified owner-occupiers of apartments as a segment of the market that was not well catered for. Each in their own way was aiming to create a new product, if not a new market.

\section{Economic theory}

Within the market design literature the analogy often cited to explain the concept is the search for marriage partners, so it was not surprising that Clarke described what he does as, 'a dating model, isn't it, of you put this person with that person'. He was nevertheless unfamiliar with the concept of two-sided matching markets and market design. In launching Citiniche in 2012 then Victorian Government Architect, Geoffrey London described Citniche as a 'housing dating bureau' (Edgar, 2013). Citiniche reflects the impetus behind two-sided matching markets, clearly attempting to establish pools of segmented demand one side and suppliers (developers, architects and other industry professionals) on the other. 
Dullroy was familiar with the economic theory of market design but argued his model went much further.

The particular model that we would classify ourselves would be a marketplace network... So a marketplace network is not just a matching service between two sides. It does that, but it also creates a network of other services and builds on top of that. So you have a network of individuals communicating about a topic. Then you have a marketplace of swapping, selling ideas or projects. On both sides, you're able to find ways of offering services and making revenue... Or it's also called a networked marketplace. (Dullroy)

\section{Community building}

Dullroy's conceptualisation immediately draws attention to network economics a field related to market design, but also to changing social practices that relate to the internet. Importantly, he highlights the issues of product definition, messages, truthful reporting, and the linkages among markets. For Group Estate the product is not simply a dwelling, nor simply the opportunity to purchase a dwelling. The commoditisation of housing is removed. Instead, the product is membership of a community and co-production.

Citiniche is also premised on the creation of communities (or niches) of interest, whether it is, for example, the desire to live in an environmentally sustainable development or pet ownership. Similarly, the intention of Nightingale Housing is to create communities not just buildings. While Apartment Register was not attempting to aggregate buyers into communities, Clarke was well aware of his clients' preference to live in small boutique developments and strong preference for higher environmentally sustainable design outcomes.

\section{Cost savings + Improved design}

Aggregation of potential purchasers was understood firstly as a means by which purchasers could get the product that they wanted but also as a means of avoiding costs, of shortening the development project timeline, and mitigating settlement risk.

My instinct is it will bring down prices, particularly if projects are totally subscribed. (Rijavec, cited in Edgar, 2013)

Clarke was particularly critical of the traditional development model and the costs of launching projects overseas.

For years that we would launch projects... and you'd think this was ridiculously expensive. You'd have to travel, you'd have to rent hotel rooms and ads in papers (Clarke)

Dullroy argued that despite the baugruppen model being both popular and successful in Germany, baugruppen projects still have a search problem.

Every baugruppen that exists has an organiser who's already paying money to somebody to try and find members. Usually, they're doing it a very inefficient way. They're usually doing it through old-fashioned vehicles.... So they're paying a monthly fee on web platforms to try and reach people who don't understand what a baugruppen is and don't particularly care. So that's wasted money. Or they're putting ads in newspapers, which is an antiquated system... Or they're going 
around sticking up flyers in the street. You know, they're doing all these types of activity. So people are already spending money on promoting it. So what we're trying to do is provide a more efficient way to spend that money. (Dullroy)

Dullroy, Clarke and McLeod each noted buyers spend an extensive period of time educating themselves prior to making a purchase, in part because they needed to sort through a barrage of unnecessary market information. Dullroy and Clarke's internet platforms had taken on the role of market intermediaries: to provide accurate and reliable information, and to vet market participants.

It's all about track record...I vet them and ask questions and ensure that they've got finance and the builder is in place...Because you want a client for life, you don't want to have, in ten years' time, a structural issue with a first time builder or developer... we would never present something that we didn't feel $100 \%$ comfortable in. (Clarke)

\section{Trust}

But the platforms and the deliberative developers are also attempting to reshape the market, in effect, create a new market, one in which transactions would be, by definition, safe for their participants. They understood this as trust and integrity, but also as much more than the traditional idea of good service. 'Truthfulness' they understood firstly in terms that it was not just their own behaviour or that of their suppliers, but also that of the buyer or member. That is, both themselves as intermediary and the supply and demand sides of the market.

People need to have a lot of trust, particularly about the idea of joining a project...Every project that comes through Group Estate, we check first. We do a simple check of it to make sure it's not some kind of scam...we call up the person who's organising it and ask them about what they want to do. We've had some people try and put some projects there that we don't think are serious enough or that have a strange concept behind them that we don't put online. So we do check to make sure that each project is somewhat legitimate.... So people have some inventive concepts about what to do with housing, but they haven't really thought through the process... we ask them to go away and do a lot of thinking before they use our platform to try and convince other people to join (Dullroy)

In Riley's syndicate model the members are legally separately and jointly liable. This means disclosure is vitally important.

I do check everybody. I sort of work with a broker and part of the process is I ask people to fill out sort of a statement of financial position and introduce them to the broker that I use and she sort of vets them really...it's almost like the brand actually becomes the people in the group and the last thing I want is for there to be any risks for the group... I'm not so worried about the business. I'm worried about the people in that project because that's the most immediate concern. (Riley)

\section{Attachment}


When pre-sales contracts are involved, the aim is that each pre-sale should settle in due course. Clarke and McLeod believed increasing the 'stickiness' of the buyers who purchase off the plan mitigates settlement risk. For Clarke this meant asking the question "Are we building the correct product here?" That is, attachment is a function of providing what the buyer wants, rather than trying to make them accept an apartment they are not entirely satisfied with. For McLeod, attachment is a key aim the process.

A distinction of the Nightingale Housing is its responsiveness to consumer demand. The attention gained by The Commons resulted in Breathe Architecture having a waiting list of more than 620 people (as of October 2015), without having undertaken any marketing. The architects are able to survey and interview prospective buyers regarding needs, design, materials, price, and owners' corporation costs and plans. Each Nightingale Housing project proponent holds regular meetings of the buyers who are privy to project financials including who is getting paid for what. Truthfulness is the modus operandi of the Nightingale Housing but the model also requires clients to engage in truthful reporting about what they want, their financial capacity, and commitment to the process.

\section{Design and transparency}

The benefits of aggregating demand for apartment development means there is a strong incentive for truthful reporting and information disclosure. As noted, a key means by which settlement risk can be avoided is by enhancing the buyer's attachment to their future home. Our informants identified greater responsiveness to actual preferences as a measure to achieve this. However, actual preferences can be difficult to guarantee, firstly because there is a degree of competition between buyers as each buyer may, for example, want the same location within the building. Secondly each individual's preferences can affect what the other individuals are able to have. Thirdly, because planning permit approval is gained after design proposals are submitted, and permit conditions may require redesign.

Design of the apartments is therefore subject to a dynamic process in which many trade-offs are necessary. Each participant needs to be sure they will obtain a dwelling that will broadly meet their expectations, however each also has an interest in ensuring other participants do not withdraw and threaten orderly settlement. At the same time the participants need to feel that other participants will not unfairly gain if they compromise. To make the process work everyone one needs to feel safe, and truthful reporting is required. Riley and McLeod resolved this by instituting an allocations process based on a queue with allocations made only once permits were secured and final costs known.

It's only really at that point do we know exactly what we're going to get because the town planning permit is approved - how much it's going to cost and then what's it worth. So it's quite a way down the process, but actually I found the benefit of that is that everybody needs to be happy with the design because they know up to that point that they could end up with any of the units. And so actually it means that the decision-making is a lot more... I think people are a bit more holistic. You know, they're making the decisions in the best interests of the overall project rather than getting worked up about well I want my unit to be like this. (Riley)

In Riley's case the queue order is determined by when the equity investor joined the project, with the first investor in the queue getting the first and hence broadest choice. McLeod 
conducted a ballot to determine the queue - with Mayor of the City of Moreland drawing 'winners' out of a hat. The winners group was still larger than the number of apartments to allow for drop out prior to the signing of pre-sale contracts: it was assumed that there may be some drop out if not all buyers were able to obtain their first choice of apartment. Risk of genuine force majeure preventing a pre-sale contract from settling is also mitigated by a reserve list of buyers. The desired quality and price is only obtainable in these projects because the participants cooperate rather than compete.

So far we have discussed many of the key elements that are of concern to market designers when they are creating a new matching market or fixing an existing market. Our informants were clear that the market needed fixing and that part of the problem was demand for specific product that the market was not supplying. Our informants recognised the need to aggregate the demand-side and match demand to supply-side development opportunities to address search costs and risk. They were keenly aware of the importance of getting the product definition right. The internet was identified as the key means by which searching and matching could occur but only if their participants could feel safe and if information flowed.

Outstanding issues to be covered are those of linkages between markets, thickness and congestion, which we turn to next. Thickness as discussed previously refers to the need for a level of activity that enables participants plenty of choice and opportunity to make comparisons, and congestion relates to that choice being exercised with ease and without disruptions. Again using Uber there is no point having many riders if there are too few drivers, or if usage is so high that the system itself cannot process transactions in real time. Linkages between markets refers to the impact of other markets on the market in question.

\section{Linked markets}

Much of the time and risk of apartment development relates to the linkages between markets. Property development is made up of sequential steps, involving many other markets, to which it is highly sensitive. One is land. Procurement of sites according to Riley and McLeod takes very considerable time, and the newer Nightingale Housing sites were more expensive than hoped. Another market is credit. Developers need to obtain equity and debt finance, and most buyers require mortgage finance. Availability and cost of credit are significant variables affecting development. The labour market is vital; if the rate of unemployment rises pre-sales will slow and settlements can be put at risk as demand falters. There are many others such as building materials, skilled labour, utility connections, all of which can impact on time and cost of a project.

The clearest connection between market design and linkages in markets is demonstrated by Nightingale Housing projects which have been able to secure a higher proportion of debt finance thus realising significant cost savings. Debt financiers were convinced by the argument that aggregating buyers and increasing their attachment the specific projects significantly reduced settlement risk and project costs. 
Finally, what was the view of our informants regarding thickness and congestion? Riley argued that if a syndicate could be formed and obtain development finance it meant there was sufficient thickness. This metric indeed has long been the test of market demand in the residential development industry.

None of the informants saw lack of demand as a problem, and perceived a more than adequate number of supply-side actors who could enter such a restructured market. To the contrary, too much demand (and raised consumer expectations) was regarded as threat by McLeod who identified obtaining development sites as a critical supply issue. In relation to congestion, Clarke's response was 'just put more people on the ground' which reflected the proposition put by all of them that their businesses could easily be scaled up. The success of these early projects and platforms suggests that a properly functioning two-sided apartment development market may be able to operate at a quite small scale and may not be limited by growth.

\section{Conclusion}

Urban consolidation policies in Australia presume new apartment supply will address Australia's chronic housing supply deficit and place downwards pressure on housing prices. Policy however has failed to consider how the development process affects tenure options and thus the apartment product brought to market. The vast bulk of policy analysis is industrylead rather than consumer-lead. A consumer lens identifies there is no market for middleincome would be owner-occupiers of new apartments because the current development model does not deliver product they are happy to buy.

The implications, which are discussed daily in the mainstream media are city landscapes of high-rise developments that are poorly constructed, occupied by a floating population of renters and partygoers in short term lets (if they are occupied at all): popularised as the 'slums of tomorrow'. Moreover, and more seriously, the predominance of investors aggravates the problem of declining housing affordability and stability in the finance sector. Australian banks have started pulling out of both financing developments and mortgage lending for inner city apartments as defaults on settlement rise with in line with speculation that there is an apartment glut and that apartment values are falling. Whether there is a glut or not is largely irrelevant: once market sentiment turns it becomes a self-fulfilling prophecy.

The question for policymakers is how to achieve requisite supply at an affordable price point, and how to smooth the boom and bust cycle that characterises property development? We argue that public policy advantages investors in apartments over would be owner-occupiers in effect owner-occupiers are crowded out, and with that is a foregone legacy of well built, quality buildings that add to the built environment rather detract from it as do most investorlead developments. Speculation as the driver for development needs to be curtailed. The gap in supply can be filled by deliberative development with a two-sided matching market progressing an orderly development process.

Our interviews suggest that apartment development is following this trend, with aggregation a key measure to manage demand, which in turn enables segmentation of demand and greater attentiveness to what owner-occupiers want. Responsiveness to demand promotes buyer stickiness and readiness to settle their pre-sale contracts. For deliberative developers the reduction in development risk permits a reduction the cost of the apartments. For mainstream developers this reduced risk permits higher quality product at a competitive price. 
Findings therefore confirm that 'uberised' apartment development can shift power from developers (as intermediaries) to consumers and their suppliers, who through do-it-yourself deliberative development can make very considerable savings. Thus market design - or uberisation - is improving housing affordability.

While the intention here has been to find a way of delivering apartments that are more affordable and of a better standard, the implications may be more profound given the prospect of more orderly development dampening speculative booms and busts. The rise of the socalled 'sharing economy' as the term suggests hints at cooperation as a key strategy for enabling improved productivity in many markets, or in bringing new markets into existence.

Understanding of market design outside of the economics, information technology and to a lesser extent management disciplines appears to be rare, despite its widespread contribution to the growth of e-commerce. This research provides an early insight into the evolving trend of digital disruption in housing markets. This research is innovative as it introduces theoretical understandings gained from other digitally disrupted markets and market design theory and applies them to housing supply and housing affordability.

\section{References}

Albrecht, J. Anderson, A. Smith, E and Vroman, S. (2007) "Opportunistic Matching in the Housing Market." International Economic Review, Vol.48 No. 2, pp. 641-664.

Birrell, B. and Healy, E. (2013) Melbourne's high-rise-apartment boom. Centre for Population and Urban Research, Monash University, Melbourne.

Bryant, L. (2012) "An Assessment of Development Funding for New Housing post-GFC in Queensland, Australia"' International Journal of Housing Markets and Analysis, Vol. 5 No. 2, pp. 118-133.

Burke, T. (2012) "The Australian residential market: institutions and actors", Tomlinson, T. (Ed) Australia's Unintended Cities: The Impact of Housing on Urban Development. CSIRO Publishing, Collingwood: pp. 35-50.

Coiacetto, E. (2009) "Industry Structure in Real Estate Development: Is City Building Competitive?" Urban Policy and Research, Vol. 27 No. 2, pp: 117-135.

Cooney, M. (2008). A better design of the market for vocational education and training in Australia? Per Capita, http://www.percapita.org.au/ dbase upl/A\%20better\%20design3.pdf) (accessed 20/7/2016)

Crowe, M. (2008) BushTender: rethinking investment for native vegetation outcomes: the application of auctions for securing private land management agreements, Dept. of Sustainability and Environment, Melbourne.

Dolin, A, London, G. and McQuoid, K. (1992) Sector 4 Housing: a Concept to Address the Need for Urban Consolidation and Better Communities - A Report to The Office of The Family, Government of Western Australia. The Rowland Company, Perth.

Edgar, R. (2013) "Standing out in a crowd", The Age, 12 April 2013, http://www.theage.com.au/victoria/standing-out-in-a-crowd-20130412-2hr6s.html 
(accessed 6/11/2015)

Erev, I., Roth, A., Slonim, R. and Barron, G. (2002) "Predictive value and the usefulness of game theoretic models", International Journal of Forecasting, Vol. 18, pp. 359-368.

Gale, D. and Shapley, L. (1962) "College Admissions and the Stability of Marriage", American Mathematical Monthly, Vol. 69, pp. 9-15.

Goeree, J., Wooders, J. and Plott, C. (2004) "Bidders' choice auctions: raising revenues through the right to choose", Journal of the European Economics Association, Vol. 2 No.2-3, pp. 504-515.Genesove, D. and Han, L. 2012 "Search and matching in the housing market", Journal Of Urban Economics, Jul, Vol.72 No.1, pp.31-45

Government of Victoria (2015) Better Apartments A Discussion Paper, Office of the Victorian Government Architect and the Department of Environment, Land, Water and Planning, Melbourne.

Kittsteiner, T. and Ockenfels, A. (2006) "Market design: a Selective Review", Fabel, O. and Franck, E. (Eds.), Governance innovations and strategies. Springer Gabler, Wiesbaden, pp. 121-143.

Kwasnica, A. and Sherstyuk, K (2013) "Multiunit auctions", Journal of Economic Surveys, Vol.27 No.3, pp.461-490.

Lloyd, M., Peel, D. and Janssen-Jansen, L. (2015) "Self-build in the UK and Netherlands: mainstreaming self-development to address housing shortages?", Urban, Planning and Transport Research, Vol. 3 No. 1, pp. 19-31.

Milgrom, P. (2011) "Critical issues in the practice of market design", Economic Inquiry, Vol. 49 No. 2, pp. 311-320.

Myerson, R. (1991) Game Theory: Analysis of Conflict. Harvard University Press, Cambridge, MA.

NHSC (National Housing Supply Council) (2013) Housing Supply and Affordability Issues 2012-13. Commonwealth of Australia, Canberra.

Ring, K. (2012) Self Made City. Jovis, Berlin.

Roth, A. (1984) "The evolution of the Labor Market for Medical Interns and Residents: A Case Study in Game Theory". Journal of Political Economy, Vol. 92, pp. 991-1016.

Roth, A. (2002) "The Economist as engineer: Game theory, experimentation, and computation as tools for design economics". Econometrica, Vol. 70 No. 4, pp. 1341-1378.

Roth, A. (2007) "The Art of Designing Markets", Harvard Business Review, Vol. 85 No. 10, pp. 118-126.

Rowley. S. and Phibbs. P. (2012) Delivering diverse and affordable housing on infill development sites, Final Report No.193, Australian Housing and Urban Research Institute, Melbourne.

Stoneham, G. Chaudhri, V. Ha, A. Strappazzon, L. (2003) "Auctions for conservation contracts: an empirical examination of Victoria's BushTender trial", Australian Journal of Agricultural \& Resource Economics, Vol. 47 No. 4, pp. 477-500.

Stoneham, G. O'Keefe, A. Eigenraam, Bain, D. (2012) "Creating physical environmental asset accounts from markets for ecosystem conservation", Ecological Economics, Vol. 82 pp. 
114-122.Vulkan, N., Roth, A., and Neeman, Z. (2013) The Handbook of market design, University Press Scholarship Online: Oxford University Press, Oxford.

Wheaton, W. (1990) "Vacancy, Search, and Prices in a Housing Market Matching Model",Journal of Political Economy, Vol. 98, No. 6, pp. 1270-1292. 